\title{
Efektivitas Pendekatan Saintifik Metode 5M dalam Peningkatan Kemampuan Menulis Karya IImiah
}

\author{
Ganes Tegar Derana, Imam Suhaimi \\ Genes1897@kahuripan.ac.id \\ Manjemen \\ Fakultas Ekonomi dan Bisnis \\ Universitas Kahuripan Kediri
}

\begin{abstract}
Abstrak
Penelitian ini merupakan kajian tentang pendekatan saintifik (dengan metode 5M) yang merupakan bagian dari implementasi kurikulum KKNI yang akan diterapkan dalam pembelajaran menulis karya ilmiah. Sehubungan dengan itu, maka tujuan penelitian adalah untuk melihat peningkatan kemampuan peserta Didik dalam kegiatan menulis karya ilmiah dengan menerapkan pendekatan saintifik (metode $5 \mathrm{M}$ ). Metode yang digunakan adalah metode quasi eksperimen, yakni eksperimen semu dengan desain one group pretest-postest. Desain tersebut hanya melihat hasil belajar peserta Didik sebelum dan sesudah perlakuan dengan pendekatan saintifik (metode 5M). Sampel yang akan dikenai perlakuan berjumlah 30 orang dari seluruh populasi yang ada. Hal itu diperoleh dari 30\% dari 103 peserta Didik tahun 2019 yang memperoleh mata kuliah Teknik Penulisan Karya Ilmiah. Sedangkan tes yang akan digunakan untuk mengukur kemampuan peserta Didik adalah tes kemampuan menulis. Tes tersebut dibuat dalam bentuk uraian. Hasil belajar diuji dengan menggunakan uji normalitas Liliefors, menguji homogenitas data dengan uji homogenitas $\mathrm{F}$, dan menguji hipotesis dengan uji-T.
\end{abstract}

Kata Kunci : Pendekatan Saintifik, Kemampuan Menulis

\begin{abstract}
This research is a study of the scientific approach (with the 5M method) which is part of the implementation of the KKNI curriculum which will be applied in learning to write scientific papers. In connection with that, the research objective is to see the increase in the ability of students in writing scientific papers by applying a scientific approach (the $5 M$ method). The method used is a quasi-experimental method, namely quasiexperimental with a one group pretest-postest design. The design only looks at the learning outcomes of students before and after treatment with the scientific approach (5M method). The sample that will be subject to treatment is 30 people from the entire population. This was obtained from 30\% of the 103 on year 2019 students who received the Scientific Paper Writing Engineering course. While the test that will be used to measure the ability of students is the writing ability test. The test is made in the form of a description. Learning outcomes were tested using the Liliefors normality test, testing data homogeneity with the F homogeneity test, and testing hypotheses with the T-test.
\end{abstract}

Key Word: Scientific approach; Writing Skills 
Jurnal PINUS: Jurnal Penelitian Inovasi Pembelajaran, 6 (1), 2020, Ganes Tegar Derana, Imam Suhaimi

\section{PENDAHULUAN}

Pendidikan merupakan daya upaya untuk memajukan budi pekerti (karakter, kekuatan bathin), pikiran (intellect) dan jasmani seseorang selaras dengan alam dan masyarakatnya. Daya dan upaya yang tertuang dalam konsep tersebut harus selaras dalam sebuah rancangan strategis yang kini disebut sebagai kurikulum.

Pelaksanaan Kurikulum KKNI seperti yang sudah dikatakan di atas, dilaksanakan melalui Pendekatan Saintifik (Scientific). Pada pelaksanaannya, pendekatan ini menekankan pada lima aspek penting yang juga dikenal dengan istilah " $5 \mathrm{M}$ ", yaitu mengamati, menanya, mencoba, menalar dan komunikasi. Lima aspek ini harus benar-benar terlihat pada pelaksanaan pembelajaran di lapangan.

Indonesia berada di tengah-tengah dunia yang baru, dunia yang terbuka sehingga seharusnya membenahi diri untuk dapat menghadapi "thread" dari dunia luar. Itu sebabnya kurikulum KKNI lebih menekankan penilaian pada sikap, pengetahuan, dan keterampilan. Dalam hal ini, sikap adalah penilaian paling utama sebelum menilai kedua hal setelah itu.

Berdasarkan latar belakang di atas, penelitian ini merumuskan sebuah judul, yakni "Penerapan Pendekatan Saintifik (Metode 5M) dalam Konsep Kurikulum KKNI terhadap Peningkatan Kemampuan Menulis Karya Ilmiah Peserta Didik Program Studi PJKR FKIP Universitas Kahuripan Kediri Tahun Ajaran 2019/ 2020.

\section{METODE}

Metode Penelitian yang digunakan dalam penelitian ini adalah metode kuantitatif eksperimen serta variabel dependen adalah yang pertama Metode dengan kurikulum KKNI dan yang kedua metode dengan kurikulum KKNI menggunakan pendekatan saintifik metode 5M . Metode ini dipergunakan karena peneliti ingin mengetahui hasil peningkatan pembelajaran kemampuan mahasiswa program studi Pendidikan Pendidikan Jasmani Kesehatan dan Rekreasi dalam mata kuliah teknik penulisan karya ilmiah sebelum dan sesudah menerapkan pendekatan saintifik (Metode 5M) dalam konsep kurikulum KKNI.

Kerangka Kualifikasi Nasional Indonesia (KKNI) merupakan perwujudan mutu dan jati diri bangsa Indonesia terkait sistem pendidikan nasional yang memungkinkan hasil dari sebuah pendidikan tinggi yang dilengkapi dengan perangkat yang memudahkan dalam melakukan penyepadanan dan penyejajaran dengan hasil pendidikan bangsa lain di dunia (DIKTI, 2014). Fungsi adanya KKNI terletak pada penyetaraan diseluruh bidang dan sektor sistem pendidikan tinggi yang terdapat dalam pelaksanaan kurikulum pendidikan tinggi.

Kerangka Kualifikasi Nasional Indonesia (KKNI) memberikan parameter ukur berupa jenjang kualifikasi dari jenjang 1 terendah sampai jenjang 9 tertinggi. Setiap jenjang KKNI bersepadan dengan level Capaian Pembelajaran (CP) program studi pada jenjang tertentu, yang mana kesepadannya untuk pendidikan tinggi 
Jurnal PINUS: Jurnal Penelitian Inovasi Pembelajaran, 6 (1), 2020, Ganes Tegar Derana, Imam Suhaimi

adalah level 3 untuk D1, level 4 untuk D2, level 5 untuk D3, level 6 untuk D4/S1, level 7 untuk profesi (setelah sarjana), level 8 untuk S2, dan level 9 untuk S3. CP pada setiap level KKNI diuraikan dalam diskripsi sikap dan tata nilai, kemampuan, pengetahuan, tanggung jawab dan hak dengan pernyataan yang ringkas yang disebut dengan deskriptor generik. Masing masing deskriptor mengindikasikan kedalaman dan level dari CP sesuai dengan jenjang program studi.

Penelitian ini dilaksanakan di kelas perkuliahan Fakultas Keguruan dan Ilmu Pendidikan Universitas Kahuripan Kediri, khususnya ruang pembelajaran program studi Pendidikan Jasmani Kesehatan dan Rekreasi. Penelitian ini dilakukan pada semester ganjil tahun pembelajaran 2019/ 2020.

Arikunto (2019:115) menyatakan, "Populasi adalah keseluruhan subjek penelitian." Populasi dalam penelitian ini adalah seluruh mahasiswa program studi Pendidikan Pendidikan Jasmani Kesehatan dan Rekreasi semester empat yang memperoleh mata kuliah teknik penulisan karya ilmiah pada tahun 2019/ 2020 yang dirincikan dalam tabel di bawah ini.

Sampel yang akan diambil adalah $30 \%$ dari jumlah populasi yang ada yakni $30 \%$ dari 70 adalah 15 . Jumlah tersebut akan digenapkan untuk dijadikan sampel penelitian, yakni 15. Oleh karena itu, sampel penelitian ini adalah 15 orang mewakili mahasiswa program studi Pendidikan Pendidikan Jasmani Kesehatan dan Rekreasi semester empat pada tahun pembelajaran 2019/ 2020.
Sesuai dengan tujuan penelitian yang telah dikemukakan pada penjelasan sebelumnya, maka penelitian ini menggunakan desain eksperimen dengan model kelompoksebelum dan sesudah test. Model model kelompoksebelum dan sesudah test adalah metode eksperimen yang dilaksanakan pada satu kelompok saja, yaitu kelompok kelompok eksperimen. Pada tahap awal, kelompok eksperimen akan dikenai pretest berupa test menulis karya tulis ilmiah sebelum perlakuan pendekatan saintifik (metode 5M). Tahap selanjutnya, kelompok yang sama akan dikenai perlakuan pendekatan saintifik (metode 5M). Pada tahap akhir, kelompok tersebut dikenai postest setelah dikenai perlakuan pendekatan saintifik (metode 5M).

Instrumen penelitian merupakan alat bantu bagi peneliti dalam mengumpulkan data. Dalam penelitian ini alat yang digunakan untuk menjaring data adalah tes kemampuan menulis model ESL menurut Hartfield (dalam Nurgiyantoro, 2009: 307-308).

\begin{tabular}{clll}
\hline No & Aspek & Kriteria & Skor \\
\hline 1. & Isi & SANGAT & $27-30$ \\
& & BAIK- & \\
& & SEMPURNA: & \\
& & padat informasi* & \\
& substansif* & \\
& pengembangan & \\
& tesis tuntas* & \\
& relevan dengan & \\
& permasalahan & $22-26$ \\
& dan tuntas & \\
& CUKUP-BAIK: & \\
& informasi \\
& cukup* \\
& substansi \\
\hline
\end{tabular}


Jurnal PINUS: Jurnal Penelitian Inovasi Pembelajaran, 6 (1), 2020, Ganes Tegar Derana, Imam Suhaimi

\begin{tabular}{|c|c|c|}
\hline & $\begin{array}{l}\text { cukup* } \\
\text { pengembangan } \\
\text { tesis terbatas* } \\
\text { relevan dengan } \\
\text { masalah tetapi } \\
\text { tak lengkap } \\
\text { SEDANG- } \\
\text { CUKUP: } \\
\text { informasi } \\
\text { terbatas* } \\
\text { substansi } \\
\text { kurang* } \\
\text { pengembangan } \\
\text { tesis tak cukup* } \\
\text { permasalahan } \\
\text { tak cukup } \\
\text { SANGAT } \\
\text { KURANG: tak } \\
\text { berisi* tak ada } \\
\text { substansi* tak } \\
\text { ada } \\
\text { pengembangan } \\
\text { tesis* tak ada } \\
\text { permasalahan }\end{array}$ & $13-16$ \\
\hline $\begin{array}{l}\text { 2. Organ } \\
\text { isasi }\end{array}$ & $\begin{array}{l}\text { SANGAT } \\
\text { BAIK- } \\
\text { SEMPURNA: } \\
\text { ekspresi lancar* } \\
\text { gagasan } \\
\text { diungkapkan } \\
\text { dengan jelas* } \\
\text { padat* tertata } \\
\text { dengan baik* } \\
\text { urutan logis* } \\
\text { kohesif } \\
\text { CUKUP-BAIK: } \\
\text { kurang lancar* } \\
\text { kurang } \\
\text { terorganisis } \\
\text { tetapi ide utama } \\
\text { terlihat* bahan } \\
\text { pendukung }\end{array}$ & $18-20$ \\
\hline
\end{tabular}

\begin{tabular}{|c|c|c|}
\hline & $\begin{array}{l}\text { terbatas* urutan } \\
\text { logis tetapi tak } \\
\text { lengkap } \\
\text { SEDANG- } \\
\text { CUKUP: tak } \\
\text { lancar* gagasan } \\
\text { kacau* } \\
\text { terpotong- } \\
\text { potong* urutan } \\
\text { dan } \\
\text { pengembangan } \\
\text { tak logis } \\
\text { SANGAT } \\
\text { KURANG: tak } \\
\text { komunikatif* } \\
\text { tak terorganisir* } \\
\text { tak layak nilai }\end{array}$ & $7-9$ \\
\hline $\begin{array}{l}\text { 3. Kosak } \\
\text { ata }\end{array}$ & $\begin{array}{l}\text { SANGAT } \\
\text { BAIK- } \\
\text { SEMPURNA: } \\
\text { pemanfaatan } \\
\text { potensi kata } \\
\text { canggih* pilihan } \\
\text { kata dan } \\
\text { ungkapan tepat* } \\
\text { menguasai } \\
\text { pembentukan } \\
\text { kata kata } \\
\text { CUKUP-BAIK: } \\
\text { pemanfaatan } \\
\text { potensi } \\
\text { agak canggih* } \\
\text { pilihan kata dan } \\
\text { ungkapan } \\
\text { kadang-kadang } \\
\text { kurang tepat } \\
\text { tetapi tak } \\
\text { mengganggu } \\
\text { SEDANG- } \\
\text { CUKUP: } \\
\text { pemanfaatan } \\
\text { potensi kata }\end{array}$ & $14-17$ \\
\hline
\end{tabular}


Jurnal PINUS: Jurnal Penelitian Inovasi Pembelajaran, 6 (1), 2020, Ganes Tegar Derana, Imam Suhaimi

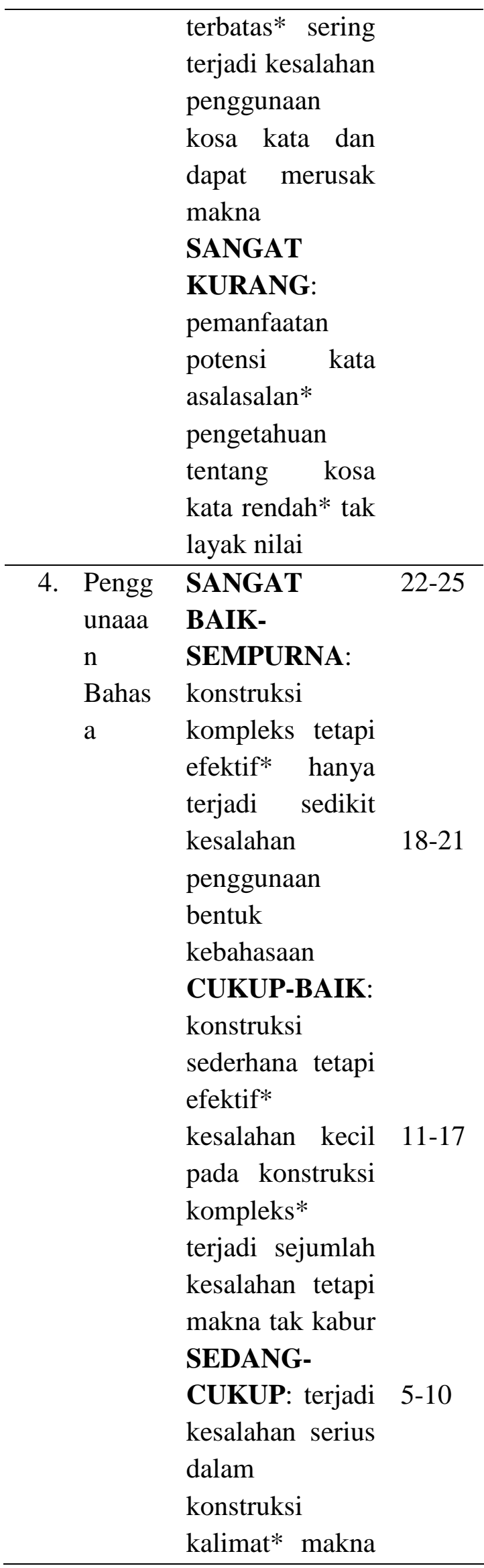

\begin{tabular}{ll}
\hline & membingungkan \\
& atau kabur \\
& SANGAT \\
& KURANG: tak \\
& mengetahui \\
& aturan sintaktis* \\
& terdapat banyak \\
& kesalahan* tak \\
& komunikatif* \\
& tak layak nilai \\
\hline Meka & SANGAT \\
BAIK- \\
SEMPURNA: \\
menguasai \\
aturan \\
penulisan* \\
hanya terdapat 4 \\
beberapa \\
kesalahan ejaan \\
CUKUP-BAIK: \\
kadang-kadang \\
terjadi kesalahan 3 3 \\
ejaan tetapi tak \\
mengaburkan \\
makna \\
SEDANG- \\
CUKUP: sering \\
terjadi kesalahan 2 \\
ejaan* makna \\
membingungkan \\
atau kabur \\
SANGAT \\
KURANG: tak \\
menguasai \\
aturan \\
penulisan* \\
terdapat banyak \\
kesalahan \\
\\
\end{tabular}


Jurnal PINUS: Jurnal Penelitian Inovasi Pembelajaran, 6 (1), 2020, Ganes Tegar Derana, Imam Suhaimi

\begin{tabular}{ll}
\hline Jumla & 100 \\
$\mathrm{~h}$ & \\
\hline
\end{tabular}

Langkah-langkah yang dilakukan dalam menganalisis adalah sebagai berikut.

1. Menghitung nilai rata-rata hasil belajar membuat proposal penelitian ilmiah sebelum dan sesudah perlakuan dengan rumus $\bar{X}=\frac{\sum F_{i} X_{i}}{\sum F_{i}}$

(Sudjana, 2002:67)

2. Menghitung simpangan baku S1 dan S2 dari varians sebelum dan sesudah perlakuan dengan rumus

$$
\mathrm{S}^{2}=\frac{N \sum F_{i} X_{i}^{2}-\left(\sum F_{i} X_{i}\right)^{2}}{N(N-1)} \quad \text { (Sudjana, 2002:95) }
$$

3. Pemeriksaan dengan uji normalitas data dengan menggunakan uji Liliefors, langkah-langkah yang ditempuh adalah:

a. Pengamatan $\mathrm{X} 1, \mathrm{X} 2, \ldots, \mathrm{X}_{\mathrm{n}}$ dijadikan bilangan baku $\mathrm{Z} 1$, $\mathrm{Z2}, \quad \ldots . \mathrm{Z}_{\mathrm{n}} \quad$ dengan menggunakan rumus:

$$
\mathrm{Z}_{i}=\frac{X_{i}-\bar{X}}{S} \quad \text { (Sudjana, 2002:466) }
$$

b. Menghitung peluang $F(z i)=$ $\mathrm{F}$ (z zi) dengan menggunakan daftar distribusi normal baku.

c. Menghitung Z1, Z2, ...,Zn yang dinyataka dengan $\mathrm{S}(\mathrm{Zi})$

d. Menghitung selisih $\mathrm{F}\left(\mathrm{Z}_{\mathrm{i}}\right)$ $\mathrm{S}\left(\mathrm{Z}_{\mathrm{i}}\right)$ kemudian menentukan harga mutlaknya.

\section{HASIL PENELITIAN}

Perbedaan rata-rata peningkatan kemampuan pemahaman matematis lebih besar dari rata-rata peningkatan pemahaman matematis untuk kelas pembelajaran konvensional, dimana nilai rata-rata peningkatan pemahaman matematis untuk kelas pembelajaran TPKI adalah 0,6330 dan nilai rata-rata peningkatan pemahaman matematis untuk kelas konvensional sebesar 0,3115, sehingga kalau dihitung selisih perbedaannya adalah 0,3215. Disisi lain diperoleh hasil perhitungan nilai t untuk pemahaman matematis untuk TPKI adalah 30,260 dan Konvensional adalah 13,835 .

Perbedaan rata-rata peningkatan kemampuan pemahaman matematis lebih besar dari rata-rata peningkatan pemahaman matematis untuk kelas pembelajaran konvensional, dimana nilai rata-rata peningkatan pemahaman matematis untuk kelas pembelajaran TPKI adalah 0,6197 dan nilai rata-rata peningkatan pemahaman matematis untuk kelas konvensional sebesar 0,3209, sehingga kalau dihitung selisih perbedaannya adalah 0,2988. Disisi lain diperoleh hasil perhitungan nilai t untuk Kreativitas matematis untuk TPKI adalah 32,553 dan Konvensional adalah 10,570

Tidak terdapat peningkatan secara bersamaan yang disumbangkan oleh pembelajaran dan PAM dan potensi awal Teknik Penulisan Karya Ilmiah Peserta Didik terhadap kemampuan pemahaman dan kreativitas matematis Peserta Didik.

Tidak adanya interaksi ini lebih cenderung mengarah pada suatu pengambilan kesimpulan yang menyatakan bahwa peningkatan pemahaman dan kreativitas matematis peserta Didik dipengaruhi sepenuhnya oleh model pembelajaran pencapaian konsep yang telah diinovasi.

\section{PEMBAHASAN}


Jurnal PINUS: Jurnal Penelitian Inovasi Pembelajaran, 6 (1), 2020, Ganes Tegar Derana, Imam Suhaimi

Berdasarkan penelitian yang telah dilakukan terhadap sampel ditemui bahwa sebahagian besar peserta Didik telah memahami organisasi penyusunan tulisan dengan baik, namun belum mampu menuangkan ide dan gagasan dalam bentuk kosakata pada tulisannya masing-masing. Selain itu, peserta Didik juga telah mampu mencantumkan data faktual berupa informasi pada substansi tulisan, meski beberapa di antaranya belum mampu menggunakan mekanisme ejaan dan tanda baca dengan baik.

Nilai yang paling besar di antara harga-harga mutlak selisih pada pretest adalah $\left(\mathrm{L}_{\text {hitung }}\right)=0,1604$ dan postest $\left(L_{h i t u n g}\right)=0,1152$. Kemudian nilai $L_{\text {hitung }}$ ini diproyeksikan dengan nilai kritis $\mathrm{L}_{\text {tabel }}$ 0,161 dengan taraf nyata $\alpha=0,05(5 \%)$ dan 0,187 dengan taraf nyata $\alpha=0,01$ (1\%). Dalam hal ini, untuk data pretest Lo $<$ Lt tampak pada $0,187<0,1604>0,161$ (pada taraf $\alpha=0,01$ ) dan untuk data postest juga Lo $<$ Lt yang terlihat pada $0,187<0,1152>0,161$ (pada taraf $\alpha=$ $0,01$ dan $\alpha=0,05)$. Dengan demikian, data pretest dan postest berdistribusi normal.

Pengujian homogenitas pada penelitian ini memperoleh $F_{\text {hitung }}$ sebesar 0,67 yang dikonversikan pada harga $\mathrm{F}_{\text {tabel }}$ pada taraf kepercayaan $95 \%$ dengan $\mathrm{dk} 1$ adalah 1,84 dan $99 \%$ adalah 2,38. Oleh karena itu, $F_{\text {hitung }}<F_{\text {tabel }}$ yaitu $0,67<1,84$ ttabel $=10,5>2,46$ berarti Ho ditolak dan Ha diterima yaitu menyatakan bahwa terdapat perbedaan yang signifikan antara kemampuan menulis sebelum dan sesudah menerapkan pendekatan saintifik (metode 5M).

Hasil penelitian di atas telah menjelaskan bahwa perolehan nilai rata- rata Peserta Didik meningkat setelah adanya perlakuan pendekatan saintifik.

\begin{tabular}{llll}
\hline No. & $\begin{array}{l}\text { Nama } \\
\text { (alias) }\end{array}$ & Pretest & Postes \\
\hline 1. & S.S & 77 & 85 \\
\hline 2. & M.S & 67 & 75 \\
\hline 3. & A.L.S & 76 & 87 \\
\hline 4. & D.P & 81 & 89 \\
\hline 5. & N.W.S & 69 & 80 \\
\hline 6. & M.A.S & 60 & 75 \\
\hline 7. & R.C.S & 76 & 85 \\
\hline 8. & D.P & 71 & 80 \\
\hline 9. & M.S & 69 & 76 \\
\hline 10 & Y.S.G & 60 & 65 \\
\hline 11 & D.S.P & 60 & 65 \\
\hline 12 & Y.H.P & 75 & 85 \\
\hline 13 & N.L.S & 67 & 75 \\
\hline 14 & R.W & 65 & 80 \\
\hline 15 & F.M.T & 65 & 80 \\
\hline
\end{tabular}

Nilai rata-rata pretest yang awalnya 68,3 meningkat menjadi 77,2. Peningkatan nilai tersebut dipengaruhi oleh adanya kontribusi pendekatan saintifik dalam meningkatkan kemampuan Peserta Didik berpikir saintifik. Selain itu, lima metode yang dikonsep dalam pendekatan tersebut mengarahkan peserta Didik untuk mendapatkan pengetahuan secara inkuiri sehingga lebih bertahan lama.

Adanya proses mengamati, menanya, menalar, mengasosiasikan, dan mengkomunikasikan membuat Peserta Didik memahami pembelajaran menulis secara terperinci dan memerolehnya dengan langkah-langkah yang sistematis. Pemahaman tersebut tampak pada substansi tulisan yang berorientasi pada data faktual, organisasi tulisan dengan konsep apa, mengapa, dan bagaimana, 
Jurnal PINUS: Jurnal Penelitian Inovasi Pembelajaran, 6 (1), 2020, Ganes Tegar Derana, Imam Suhaimi

serta mekanisme penggunaan ejaan dan tanda baca.

Berdasarkan pemaparan tersebut, di antara lima aspek penelitian, yakni isi, organisasi, bahasa, kosakata, serta mekanisme, hanya aspek penuangan ide dalam aspek isi yang belum dapat dipahami oleh peserta Didik. Hal ini, dibutuhkan latihan yang intens untuk menuangkan ide dengan baik dalam bentuk tulisan.

\section{KESIMPULAN DAN}

Kesimpulan penelitian ini adalah sebagai berikut. Kemampuan menulis sebelum menerapkan pendekatan saintifik memiliki rata-rata 68,3 . Kemampuan menulis sesudah menerapkan pendekatan saintifik memiliki rata-rata 77,2.

Data kemampuan menulis sebelum dan sesudah menerapkan pendekatan saintifik berada pada distribusi normal, yaitu pada taraf $\alpha=$ $5 \%, \alpha=1 \%$, dan $\mathrm{N}=30$ diperoleh $\mathrm{L}_{\text {hitung }}<$ $\mathrm{L}_{\text {tabel }}\left(0,1604<0,161_{(0,05)}<0,187_{(0,01)}\right)$ sebelum perlakuan dan $\mathrm{L}_{\text {hitung }}<\mathrm{L}_{\text {tabel }(0,1152}$ $<0,1568(0,05)<0,1824(0,01)$ ) sesudah perlakuan. Artinya, kedua data tersebut berasal dari populasi yang berdistribusi normal.

Penelitian ini menunjukkan bahwa variasi berasal dari populasi yang bersifat homogen dengan $F_{\text {hitung }}<\mathrm{F}_{\text {tabel }}$ yaitu $0,67<1,84$.

Kesulitan peserta Didik dalam mencantumkan data faktual pada substansi tulisan, menyusun organisasi tulisan, serta menggunakan mekanisme ejaan dan tanda baca dapat diatasi dengan penerapan pendekatan saintifik.

Kesulitan peserta Didik dalam menuangkan ide harus diarahkan oleh dosen dengan waktu yang cukup lama dan latihan intensif untuk dapat memproduksi kosakata dan penalaran yang baik dalam tulisan.

Dari hasil penelitian dan data yang diperoleh, pendekatan saintifik cukup baik diterapkan untuk meningkatkan kemampuan peserta didik dalam memproduksi tulisan.

\section{DAFTAR RUJUKAN}

Arikunto, S.2019. Prosedur Penelitian Suatu Pendekatan dan Praktek. Jakarta: RinekaCipta.

Burhan, Nurgiyantoro.(2016). Penilaian Pengajaran Bahasa. Yogyakarta: BPFE.

Darmadi, Kaswan. (2015). Meningkatkan kemampuan Menulis Panduan untuk Peserta Didik dan Calon Peserta Didik. Yogyakarta: ANDI Yogyakarta

Omari, H. A \&Weshah, H. (2015). Using the Reciprocal Teaching Method by $\mathrm{T}$ eachers at Jordanian Schools. European Journal of Social Sciences, 15(1),26-39

Rahayu, I., dkk. 2017. Kemampuan Siswa dalam Menulis Karangan Berdasarkan Pengalaman Pribadi pada Siswa Kelas XI SMA Negeri 7 Kota Jambi: FKIP Universitas Jambi

Suyitno, Hardi. (2015). Hubungan antara bahasa dengan logika dan Teknik Penulisan Karya Ilmiah menurut pemikiran Wittgenstein. Dalam Humaniora; Journal of Culture, Literature, and Linguistics, volume 20 Nomor 1, hal. 26-37 
Jurnal PINUS: Jurnal Penelitian Inovasi Pembelajaran, 6 (1), 2020, Ganes Tegar Derana, Imam Suhaimi

Sudjana. 2018. Metoda Statistika. Bandung: Tarsito.

Sulistiyani. 2016. Peningkatan Kemampuan Menulis Narasi dengan Metode Peta Pikiran pada Siswa Kelas XII SMA Negeri 3 Surakarta. Thesis tidak diterbitkan. Surakarta: FKIP Sebelas Maret.

Mudjiono, Yoyon. (2016). Komunikasi Sosial. Dalam Jurnal Ilmu Komunikasi, Volume 2, Nomor 1, April 2012, hlm. 99-112.
Zaini,H. Bermawy, M. Sekar A, A. (2016). Strategi Pembelajaran Aktif. Yogyakarta: Pustaka

Zaini,H. Bermawy, M. Sekar A, A. (2016). Strategi Pembelajaran Aktif. Yogyakarta: Pustaka Komunikasi, Volume 2, Nomor 1, April 2012, hlm. 99-112.

Zaini,H. Bermawy, M. Sekar A, A. (2016). Strategi Pembelajaran Aktif. Yogyakarta: Pustaka. 